\title{
FZD4 wt Allele
}

National Cancer Institute

\section{Source}

National Cancer Institute. FZD4 wt Allele. NCI Thesaurus. Code C51448.

Human FZD4 wild-type allele is located in the vicinity of $11 \mathrm{q} 14.2$ and is approximately 10 $\mathrm{kb}$ in length. This allele, which encodes frizzled-4 protein, is involved in $\mathrm{G}$ protein-coupled receptor signal transduction and the beta-catenin canonical signaling pathway. 